\title{
PRACTICE PARAMETER: THE ROLE OF CORTICOSTEROIDS IN THE MANAGEMENT OF ACUTE MONOSYMPTOMATIC OPTIC NEURITIS
}

\author{
Report of the Quality Standards Subcommittee of the American Academy of Neurology \\ D.I. Kaufman, DO; J.D. Trobe, MD; E.R. Eggenberger, DO; J.N. Whitaker, MD
}

\begin{abstract}
Optic neuritis (ON) is an inflammatory disorder of the optic nerve. Most cases are idiopathic or associated with MS. ON can be associated with a variety of systemic or ocular disorders and is the most common acute optic neuropathy in adults younger than 46 years. Among high-risk populations for MS, the incidence of ON is about 3 per 100,000 population per year, whereas in other areas the incidence is about 1 per 100,000 population per year. ${ }^{1-13}$

Acute $\mathrm{ON}$ often presents as an isolated clinical event without contributory systemic abnormalities (monosymptomatic $\mathrm{ON}$ ). Clinical features include periocular pain, abnormal visual acuity and fields, reduced color vision, a relative afferent pupillary defect, and abnormal visual evoked potentials. The fundus may appear normal or demonstrate edema of the optic nerve head (papillitis). ${ }^{12-18}$ MRI white matter abnormalities identical to those seen in MS are found in 50 to $70 \%$ of monosymptomatic ON cases. ${ }^{19-22}$ The visual deficit of ON may worsen over 1 to 2 weeks and usually begins improving over the next month. Lack of improvement in visual function by 30 days is unusual. ${ }^{23}$ However, most patients have some residual visual function deficit, even if visual acuity improves to 20/20148 Differential diagnosis includes compressive, ischemic, hereditary, toxic, or other inflammatory optic neuropathies (e.g., sarcoid). These conditions usually do not exhibit the same clinical pattern (table 1 ) or rate of recovery as monosymptomatic $\mathrm{ON} .{ }^{1-13}$

Treatment of monosymptomatic ON has included oral, retrobulbar, and IV steroids, immunoglobulin, and acupuncture. ${ }^{23-77}$ Monosymptomatic acute $\mathrm{ON}$ is not rare and because the usefulness of oral prednisone in this disorder has recently been questioned, ${ }^{23,78-82}$ this practice parameter was developed to provide recommendations regarding the management of this common neurologic problem.
\end{abstract}

Evidence review. A literature search was conducted using Medline and Healthstar from 1966 to July 1, 1999. ON was cross-referenced with treatment and therapy. Citations earlier than 1966 were searched by cross-referencing techniques and an Index Medicus hand search. A total of 582 different citations dealing with ON and some aspect of therapy were identified and reviewed. Only literature published in well-disseminated journals dealing specifically with MS-related or idiopathic $\mathrm{ON}$ involving at least three patients was retained. Both retrospective and prospective data were reviewed. Citations were excluded when they simply described a small number of individual case reports or reviewed "ON" due to diseases such as sarcoid, lupus, anterior ischemic optic neuropathy, trauma, hereditary optic neuropathy, optic nerve compression, or other unrelated optic neuropathy.

Definitions for the classification of evidence. Class I. Evidence provided by well-designed, randomized, controlled clinical trials, including overviews (meta-analyses) of such trials.

Class II. Evidence provided by well-designed observational studies with concurrent controls (e.g., case control and cohort studies).

Class III. Evidence provided by expert opinion, case series, case reports, and studies with historical controls.

All pertinent studies are listed in table 2 .

Results. Several studies were identified, the largest of which was the National Eye Institute-sponsored Optic Neuritis Treatment Trial (ONTT). ${ }^{11,12,23,30-33,39,56-59,61-77,83-85}$ The ONTT enrolled 457 patients with acute ON, age 18 to 46 years,

From the Department of Neurology and Ophthalmology (Drs. Kaufman and Eggenberger), College of Osteopathic Medicine and College of Human Medicine, Michigan State University, East Lansing, MI; the Departments of Ophthalmology and Neurology (Dr. Trobe), W.K. Kellogg Eye Center, University of Michigan, Ann Arbor; and the Department of Neurology and Center for Neuroimmunology (Dr. Whitaker), University of Alabama at Birmingham and Research and Neurology Services, Birmingham Veterans Medical Center.

Approved by the Quality Standards Subcommittee July 24, 1999. Approved by the Practice Committee January 15, 2000. Approved by the American Academy of Neurology Board of Directors February 26, 2000..

Received May 4, 1999. Accepted in final form September 18, 1999.

Address correspondence and reprint requests to the American Academy of Neurology, 1080 Montreal Ave., St. Paul, MN 55116.

Copyright (C) 2000 by the American Academy of Neurology 
and followed them for 6 months or longer. ${ }^{23}$ The study subsequently completed 5 -year follow-up on a cohort of 388 ON patients with no history of MS..$^{83,85}$

ONTT patients were randomized into three treatment groups within 8 days of symptoms onset: 1) oral prednisone alone ( $1 \mathrm{mg} / \mathrm{kg}$ every day) for 14 days (oral treatment group); 2 ) IV methylprednisolone sodium succinate $250 \mathrm{mg}$ four times daily $(1000 \mathrm{mg} /$ day) for 3 days in hospital, followed by oral prednisone ( $1 \mathrm{mg} / \mathrm{kg}$ every day) for 11 days as outpatient (IV treatment group or IVMP); or 3) oral placebo for 14 days (placebo group). The prednisone arm of the study was double-masked, whereas the IVMP arm was single-masked. The use of a placebo IV group was not included because study organizers could not justify, ethically or financially, hospitalizing patients for 3 days of sham IV therapy. ${ }^{65,84}$

The study was designed to determine speed and level of recovery and complications of therapy. Visual acuity, visual fields, contrast sensitivity, and color vision were measured at study entry and at seven follow-up visits during the first 6 months, at 1 year, and then annually for 5 years. MRI was performed in nearly all patients at study entry. Lumbar puncture was optional and performed in 133 of 457 (29.1\%) of the cohort. ${ }^{65,84}$ Two of 457 patients were eventually discovered to have compressive ON.

Oral prednisone at $1 \mathrm{mg} / \mathrm{kg} /$ day (previously the most common method of treating $\mathrm{ON}$ ) failed to demonstrate any statistically significant improvement in the speed or degree of visual recovery compared to placebo. ${ }^{23}$ The IV treatment group, by contrast, had significantly faster visual recovery than placebo over the first 30 days $(p=0.02$ and $p=0.0001$ for the respective primary outcomes) but, after 6 months, there were no significant differences in visual acuity in the three treatment groups. ${ }^{23}$ After 12 months of follow-up, visual acuity in the study eye was better than $20 / 20$ in $69 \%$ and 20/200 or worse in only $3 \%{ }^{86}$ The only predictor of a poor visual outeome was poor visual acuity at study entry. Of 160 eyes starting at $20 / 200$ or worse, only $8(5 \%)$ were still $20 / 200$ or worse at 6 months. ${ }^{12,23,67}$

Recurrent $\mathrm{ON}$ was greater in the group treated with oral prednisone alone than in the other two groups. ${ }^{23,61,62}$ Also by year $2,30 \%$ of patients in the oral treatment group experienced at least one new attack of ON in either eye compared to $16 \%$ in the placebo group and $13 \%$ in the IV treatment group. ${ }^{23,71,75}$ This disparity among treatment groups continued throughout the 5-year follow-up period (41\% reeurrences in the prednisone treatment group and $25 \%$ in the IV and placebo groups; $p=0.004$ ). Also, the ONTT noted that IVMP was associated with reduced risk of developing clinically definite MS in patients with an abnormal brain MRI at study entry and followed for 2 years compared to the two other treatment groups ${ }^{71,83,87}$ These relationships between treatment and both recurrent $\mathrm{ON}$ and MS remain unexplained and controversial. ${ }^{78-82,88}$ Herishanu et al. ${ }^{40}$ suggested that both recurrent $\mathrm{ON}$ and ON conversion to MS were greater following the use of IVMP compared to oral prednisone. This study, however, retrospectively evaluated a total of only 26 nonrandomized patients receiving no therapy, oral prednisone or IVMP, and, therefore, provides essentially Class III evidence of any such associations.

In the ONTT the therapeutic effect of the IVMP was no longer significant by the third year of follow-up (table 3 ). ${ }^{75,83}$ Among patients with a normal MRI, the 2-year rate of MS was so low that a benefit from IV treatment could not be established (see table 3) ${ }^{83}$ The IV treatment arm of the ONTT was single masked. ${ }^{71,89}$ Patients or neurologists, using a detailed and standardized protocol months or years after therapy, are unlikely to have been biased in reporting attacks of demyelination in the IVMP group or in any of the other treatment groups. ${ }^{76}$ All patient forms were reviewed without knowledge of the treatment arm by a neurologist experienced in MS. ${ }^{76}$

Four other Class I and three other Class II corticosteroid treatment trials in ON that were relevant to this practice parameter were identified (see table 2).$^{30-33,39,56-59}$ All were prospective, randomized, and placebo-controlled studies, although employing sample sizes considerably smaller than the ONTT. Thus, these studies lack the statistical power to exclude a therapeutic benefit to steroid treatment. ${ }^{90}$ Several of these Class I studies report positive results. For example, Rawson et al. found that the speed of recovery in visual acuity was faster in patients receiving ACTH (40 units IM daily for 30 days; $p<0.01$ ) compared to placebo over the first 30 days, although by 12 months there was no significant difference between groups. ${ }^{30,31}$ Bowden et al. ${ }^{32}$ similarly demonstrated that visual acuity was the same at 12 months in patients treated with either ACTH (40 units IM daily for 30 days) or placebo. Kapoor et al. showed no effect of IVMP $(1000 \mathrm{mg} / \mathrm{d} \times 3$ days $)$ compared to placebo on the visual outcome at 6 months in 66 individuals with ON lesions involving the optic canal. ${ }^{56}$ Sellebjerg et al. studied 60 patients ${ }^{59}$ using either $500 \mathrm{mg}$ of oral methylprednisolone daily for 5 days with a 10-day taper or placebo. They reported that there was an increased speed of visual recovery in the treated group $(p=0.008)$ but no long-term benefit compared to placebo. There was no increase in recurrence of ON at 1 year using oral methylprednisolone; however, they noted that the number of patients was too low to rule out an effect on subsequent disease activity. ${ }^{59}$ 
Three Class II studies were noted. Gould et al. found that ON treated with a single dose of retrobulbar triamcinolone $(40 \mathrm{mg})$ was associated with nonsignificant increase in the speed of visual recovery but resulted in no benefit compared to placebo at 12 months. ${ }^{33}$ In 1999, Wakakura et al. evaluated 66 patients with optic neuritis treated with either 1000 mg IVMP for 3 days or mecobalamin $(500 \mathrm{mg}$ /day) and found that IVMP improved the speed of visual recovery in the first several weeks $(p<0.05)$ but that visual function at 12 weeks and 1 year did not differ between the two groups. ${ }^{13,58}$ Another oral methylprednisolone study has also been reported. The Tübingen study tested 50 patients, ${ }^{39,57} 14$ of whom

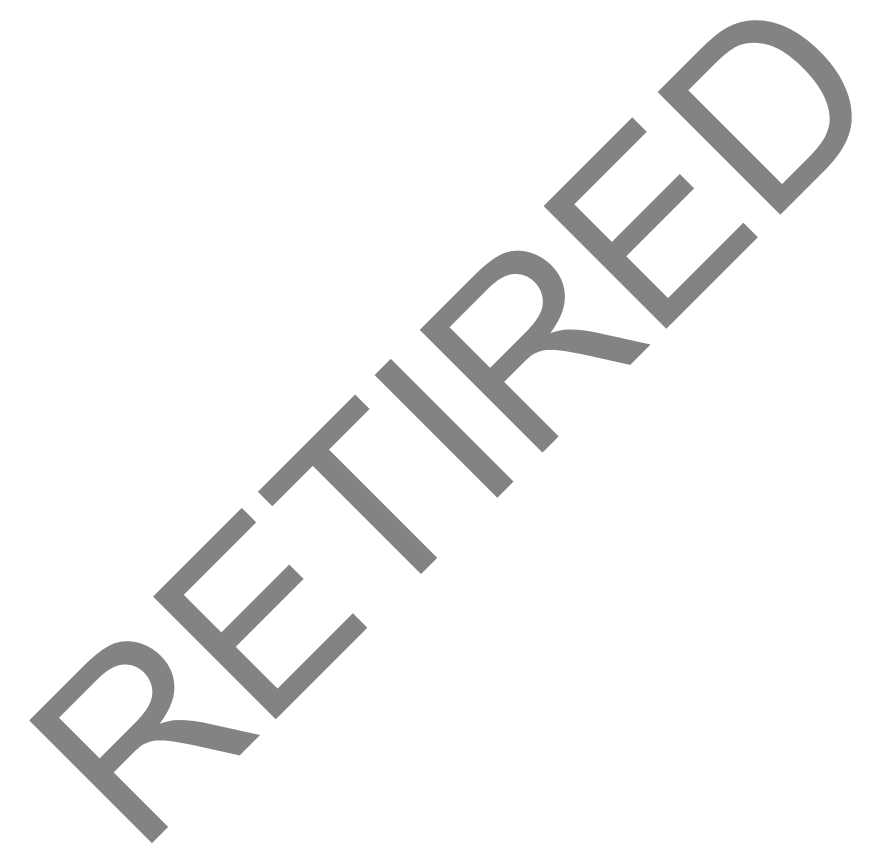


Table 2 Studies of optic neuritis (ON) classified chronologically by level of evidence

\begin{tabular}{|c|c|c|c|c|}
\hline Author and year published & Therapy used/study design & Cohort number & Outcome & Evidence class $\dagger$ \\
\hline Glaser et al., ${ }^{24} 1952$ & $\begin{array}{l}\text { IM ACTH } 80 \text { to } 100 \mathrm{mg} \text { for } 5 \\
\text { days; no control subjects }\end{array}$ & 3 & $\begin{array}{l}\text { All three patients had } \\
\text { improved VA }\end{array}$ & III \\
\hline Rucker, ${ }^{27} 1956$ & $\begin{array}{l}\text { IV ACTH vs other therapy; } \\
\text { appears retrospective and not } \\
\text { randomized }\end{array}$ & 133 & No significant difference & III \\
\hline $\begin{array}{l}\text { Giles and Isaacson, }{ }^{28} \\
1961\end{array}$ & $\begin{array}{l}\text { Steroids, vasodilator, typhoid } \mathrm{H} \\
\text { antigen; retrospective }\end{array}$ & $\begin{array}{l}\text { Steroids, } 48 \text {; vasodilator, } \\
\text { 23; typhoid } \mathrm{H} \text { antigen, } 8\end{array}$ & $\begin{array}{l}\text { No significant difference in } \\
\text { recovery }\end{array}$ & III \\
\hline Oksala, ${ }^{29} 1964$ & $\begin{array}{l}\text { Cortisone, antibiotics; } \\
\text { retrospective }\end{array}$ & $\begin{array}{l}\text { Antibiotics, } 73 \text {; cortisone, } \\
33\end{array}$ & No significant difference & III \\
\hline $\begin{array}{l}\text { Rawson et al., } 1996,{ }^{30} \\
\quad 1969^{31}\end{array}$ & $\begin{array}{l}40 \text { U IM ACTH vs placebo; } \\
\text { randomized }\end{array}$ & ACTH, 25; placebo, 25 & $\begin{array}{l}\text { ACTH faster recovery but } \\
\text { same VA by } 12 \text { mo }\end{array}$ & I \\
\hline Bowden et al., ${ }^{32} 1974$ & $\begin{array}{l}40 \text { U ACT for } 30 \text { days, placebo; } \\
\text { randomized }\end{array}$ & ACTH IM, 27; placebo, 27 & $\begin{array}{l}\text { No significant VA difference } \\
\text { at } 2,6,12 \text {, or } 24 \text { mo }\end{array}$ & I \\
\hline Gould et al., ${ }^{33} 1977$ & $\begin{array}{l}\text { Retrobulbar } 40 \mathrm{mg} \\
\text { triamcinolone, single masked } \\
\text { control subjects (no placebo), } \\
\text { 6-mo follow-up }\end{array}$ & $\begin{array}{l}\text { Triamcinolone, 26; placebo, } \\
\quad 28\end{array}$ & $\begin{array}{l}\text { Steroids gave faster recovery } \\
\text { but VA the same at } 6 \text { mo }\end{array}$ & II \\
\hline $\begin{array}{l}\text { Spoor and Rochwell, }{ }^{41} \\
1988\end{array}$ & $\begin{array}{l}1 \text { or } 2 \text { g IVMP; no control } \\
\text { subjects }\end{array}$ & 12 & All improved some by $24 \mathrm{~h}$ & III \\
\hline Herishanu et al., ${ }^{40} 1989$ & $\begin{array}{l}\text { IVMP vs prednisone vs no } \\
\text { therapy; not randomized, } \\
\text { retrospective }\end{array}$ & 26 divided into three groups & More conversion to MS with & III \\
\hline Farris and Pickard, ${ }^{42} 1990$ & $\begin{array}{l}\text { IVMP with oral prednisone; no } \\
\text { placebo }\end{array}$ & 6 & ar-total recovery & III \\
\hline Mehdorn, ${ }^{34} 1990$ & $1 \mathrm{~g}$ IVMP vs mannitol & 4 & uick recovery in both groups & III \\
\hline $\begin{array}{l}\text { Trauzettel-Klosinski et } \\
\text { al., }{ }^{39} 1991\end{array}$ & $\begin{array}{l}100 \mathrm{mg} / \mathrm{d} \text { oral MP vs thiamine } \\
\text { (as placebo); partially } \\
\text { randomized, mixed design }\end{array}$ & Thiamine & $\begin{array}{l}\text { MP improved faster; placebo } \\
\text { same as oral MP at } 12 \text { mo }\end{array}$ & II \\
\hline van Engelen et al., ${ }^{35} 1992$ & $\begin{array}{l}0.4 \mathrm{mg} / \mathrm{kg} / \mathrm{d} \text { IVIg for } 5 \mathrm{~d} \text { then } \\
\text { every } 2 \mathrm{wk} \text { for } 1 \mathrm{y} \\
\text { uncontrolled }\end{array}$ & 5 & $\begin{array}{l}\text { VA at } 3 \mathrm{mo} \\
\text { ined for }>1 \mathrm{y}\end{array}$ & III \\
\hline $\begin{array}{l}\text { Gerling and Kommerell, } \\
1992\end{array}$ & $\begin{array}{l}1 \mathrm{~g} \text { IVMP/d x five; no control } \\
\text { group }\end{array}$ & & $\begin{array}{l}\text { Rapid recovery in } 12 \text { of } 17 \\
\text { patients during treatment } \\
\text { period only }\end{array}$ & III \\
\hline $\begin{array}{l}\text { Beck et al. }{ }^{23,71,83} 1992, \\
1993,1997\end{array}$ & $\begin{array}{l}\text { Prednisone } 1 \mathrm{mg} / \mathrm{kg} / 11 \mathrm{~d} \text {; IVMP } \\
\text { g/d x } 3 \text { followed by } \\
\text { prednisone; placebo, } \\
\text { prospective, randomized, } \\
\text { placebo controlled (for } \\
\text { prednisone only) }\end{array}$ & $\begin{array}{l}\text { Placebo, 150; IVMP, 151; } \\
\text { prednisone, 156; therapy } \\
\text { within } 8 \text { days (5-year MS } \\
\text { risk assessment: placebo, } \\
\text { 126; IVMP, 134; oral } \\
\text { prednisone, 129) }\end{array}$ & $\begin{array}{l}\text { More ON recurrence with } \\
\text { prednisone than placebo; } \\
\text { IVMP speeds recovery; } \\
\text { reduced rate of onset of MS } \\
\text { for } 2 \text { y when MRI abnormal }\end{array}$ & $\begin{array}{l}\mathrm{I} / \text { prednisone } \\
\mathrm{II} / \text { methylpredisolo } \\
\text { ne }\end{array}$ \\
\hline Alejandro et al., ${ }^{55} 1994$ & $\begin{array}{l}\text { Oral prednisone } 1 \mathrm{mg} / \mathrm{kg} \text { vs } \\
\quad \text { IVMP } 500 \mathrm{mg} \text { every } 8 \mathrm{~h} \times 10\end{array}$ & IVMP, $8 ;$ prednisone, 8 & $\begin{array}{l}\text { No differences between the } \\
\text { groups regarding clinical } \\
\text { outcome; very small sample } \\
\text { size }\end{array}$ & III \\
\hline $\begin{array}{l}\text { Toczolowski et al., } \\
1995\end{array}$ & $\begin{array}{l}\text { Oral steroids vs peribulbar vs } \\
\text { IVMP; no control subjects; } \\
\text { not randomized }\end{array}$ & 98 & $\begin{array}{l}\text { IVMP more effective than } \\
\text { other methods in regaining } \\
\text { vision }\end{array}$ & III \\
\hline $\begin{array}{l}\text { Koraszewska- } \\
\text { Matuszewska et al., }{ }^{54} \\
1995\end{array}$ & $\begin{array}{l}\text { Many steroid types; unclear } \\
\text { control group; retrospective }\end{array}$ & 110 children ages 2 to $18 \mathrm{y}$ & $\begin{array}{l}\text { "Recovery" of VA in } 75 \% \text { of } \\
\text { patients }\end{array}$ & III \\
\hline Kapoor et al., ${ }^{56} 1998$ & IVMP vs placebo; randomized & $\begin{array}{l}\text { IVMP, 33; placebo, 33; all } \\
\text { had optic canal MRI } \\
\text { lesions }\end{array}$ & $\begin{array}{l}\text { Faster (nonsignificant) time to } \\
\text { recovery for IVMP vs } \\
\text { placebo }\end{array}$ & I \\
\hline Wakakura et al., ${ }^{13} 1999$ & $\begin{array}{l}\text { IVMP vs placebo } \\
\text { (mecobalamin); randomized } \\
\text { prospective; not specifically } \\
\text { listed as masked assessment }\end{array}$ & IVMP, 33; placebo, 33 & $\begin{array}{l}\text { IVMP faster recovery but the } \\
\text { same at } 12 \mathrm{wk} \text { and } 1 \mathrm{y}\end{array}$ & II \\
\hline Sellebjerg et al., ${ }^{59} 1999$ & Oral MP $500 \mathrm{mg}$ vs placebo & Oral MP, 30; placebo, 30 & $\begin{array}{l}\text { Oral MP faster recovery but no } \\
\text { difference at } 8 \text { wk }\end{array}$ & I \\
\hline
\end{tabular}

*As defined by the American Academy of Neurology Quality Standards Subcommittee.

$\dagger$ Class I = well-designed, prospective, randomized, placebo-controlled study; Class II = well-designed, observational studies; Class III = expert opinion, case series, and studies with historical control subjects.

$\mathrm{VA}=$ visual acuity; $\mathrm{MP}=$ methylprednisolone; $\mathrm{Ig}=$ immunoglobulin.

were treated patients with $100 \mathrm{mg}$ of oral methylprednisolone for 3 days, subsequently tapering the dose by $20 \mathrm{mg}$ every 3 days thereafter. At 4 weeks the treated group had a $61 \%$ better visual outcome (nearly normal function) compared to placebo (thiamine), although this was not statistically significant. By 12 months, however, no such difference was apparent. 
Thirteen Class III studies were also identified (see table 2). These included reports from the early 1950s dealing with glucocorticoid treatment of ON. ${ }^{24,27}$ All of these studies had serious methodologic flaws related to very low patient numbers, ${ }^{90}$ retrospective analysis, no randomization, or lack of placebo control..$^{24,27-29,34,35,40-42,44,53-55}$ In a 1988 publication, Spoor and Rockwell showed rapid recovery of vision (some within 24 hours) in 12 patients given 1 to $2 \mathrm{~g}$ of IVMP. This study was neither randomized nor placebo-controlled. ${ }^{41}$ A study by Alejandro et al. in 1994 looked at eight patients given IVMP versus eight patients treated with oral prednisone and found no difference between groups. ${ }^{55}$ Other studies are listed in table 2.

There are also several studies reviewing the prognostic value of MRI and CSF in determining the relative risk of developing $\mathrm{MS}$ after $\mathrm{ON}{ }^{20,60,83,91}$ However, an in-depth analysis of that work is beyond the scope of this practice parameter.

Recommendations. Definitions for the strength of recommendations were based on the following criteria:

Standard: A principle for patient management that reflects a high degree of clinical certainty (usually this requires Class I evidence that directly addresses the clinical question, or overwhelming Class II evidence when circumstances preclude randomized clinical trials).

Guideline: A recommendation for patient management that refleets moderate clinical certainty (usually this requires Class II evidence or a strong consensus of Class III evidence.

Practice Option: A strategy for patient management for which the clinical utility is uncertain (inconclusive or conflicting evidence or opinion).

Practice Advisory: A practice recommendation for emerging and/or newly approved therapies or technologies based on evidence from at least one Class I study. The evidence may demonstrate only a modest statistical effect or limited (partial) clinical response, or significant cost-benefit questions may exist. Substantial (or potential) disagreement among practitioners or between payers and practitioners may exist.

Acute monosymptomatic ON recommendations. Oral prednisone in doses of $1 \mathrm{mg} / \mathrm{kg} / \mathrm{day}$ has no demonstrated efficacy in the recovery of visual function in acute monosymptomatic $\mathrm{ON}$, and therefore is of no proven value in treating this disorder. Standard

Higher dose oral or parenteral methylprednisolone or ACTH may hasten the speed and degree of recovery of visual function in persons with acute monosymptomatic ON. There is, however, no evidence of long-term benefit for visual function. The decision to use these medications to speed recovery but not to improve ultimate visual outcome should therefore be based on other non-evidence-based factors such as quality of life, risk to the patient, visual function in the fellow eye, or other factors that the clinician deems appropriate. Guideline

Recommendations for future research. Several management issues still lack evidence for specific recommendations: 1) whether corticosteroid treatment is beneficial in patients whose symptom duration is longer than 8 days; 2) whether larger doses of corticosteroids are more effective than lower doses; 3) what the optimal corticosteroid regimen is; 4) whether the observed increased ON recurrence rate associated with oral prednisone is also observed in MS attacks; and 5) whether high-dose methylprednisolone given periodically will improve the prognosis for patients with MS.

Disclaimer. This statement is provided as an educational service of the American Academy of Neurology. It is based on an assessment of current scientific and clinical information. It is not intended to include all possible proper methods of care for a particular neurologic problem or all legitimate criteria for choosing to use a specific procedure. Neither is it intended to exclude any reasonable alternative methodologies. The AAN recognizes that specific patient care decisions are the prerogative of the patient and the physician caring for the patient, based on all of the circumstances involved. 


\section{Acknowledgment}

The American Academy of Neurology Quality Standards Subcommittee thanks David I. Kaufman, DO, for his service to the Academy's membership as the lead author of this practice parameter; Michael Greenberg, MD, and Gary Franklin, MD, MPH, for facilitating this project; Jonathon Trobe, MD, Eric Eggenberger, DO, and John N. Whitaker, MD, for providing their expertise, time, and insight into the development of this document; and Sandy Holliday, for her help in bringing this manuscript to conclusion.

They also thank the numerous individuals, AAN Sections, and organizations that reviewed drafts of this practice parameter, including the American Academy of Ophthalmology, National MS Society, MS Society of Canada, AB Baker Section, Government Services Section, MS Section, Neuro-Ophthalmology/Neuro-Otology Section, Neuroimaging Section, Pain Section, Sleep Section, Spine Section, and the Stroke Section.

\section{Appendix}

American Academy of Neurology Quality Standards Subcommittee Members: Gary Franklin, MD, MPH-Co-Chair; Catherine Zahn, MD-Co-Chair; Milton Alter, MD, PhD; Stephen Ashwal, MD; John Calverley, MD; Richard Dubinsky, MD; Jacqueline French, MD; Michael Greenberg, MD; Gary Gronseth, MD; Deborah Hirtz, MD; Robert Miller, MD; James Stevens, MD; and William Weiner, MD.

\section{References}

1. Rizzo JF, Lessell S. Risk of developing multiple sclerosis after uncomplicated optic neuritis. A long-term prospective study. Neurology 1988;38:185-190.

2. Ebers GC. Optic neuritis and multiple sclerosis. Arch Neurol 1985;42:702-704.

3. Kurtzke JF. Optic neuritis or multiple sclerosis. Arch Neurol 1985;42:704-710.

4. Francis DA, Compston DAS, Batchelor, McDonald WI. A reassessment of the risk of multiple sclerosis developing in patients with optic neuritis after extended follow up. J Neurol Neurosurg Psychiatry 1987;50:758-765.

5. Sandberg-Wolheim M, Bynke H, Cronqvist S, et al. A long-term prospective study of optic neuritis: evaluation of risk factors. Ann Neurol 1990;27:386-393.

6. Perkin GD, Rose FC. Optic neuritis and its differential diagnosis. New York: Oxford, 1979:226-248.

7. Nikoskelainen E. Later course and prognosis of optic neuritis. Acta Ophthalmol 1975;53:273-291.

8. Hutchinson WM. Acute optic neuritis and the prognosis for multiple sclerosis. J Neurol Neurosurg Psychiatry 1976;39:283-289.

9. Hely MA, McManis PG, Doran TJ, Walsh JC, McLeod JG. Acute optic neuritis; a prospective study of risk factors for multiple sclerosis. J Neurol Neurosurg Psychiatry 1986;498:1125-1130.

10. Wakakura M, Ishikawa S, Oono S, et al. Incidence of acute idiopathic optic neuritis and its therapy in Japan. Optic Neuritis Treatment Trial Multicenter Cooperative Research Group. Nippon Ganka Gakkai Zasshi 1995;99:93-97.

11. Beck RW. The Optic Neuritis Treatment Trial. Arch Ophthalmol 1988;106:1051-1053.

12. Optic Neuritis Study Group. The clinical profile of acute optic neuritis: experience of the Optic Neuritis Treatment Trial. Arch Ophthalmol 1991;109:1673-1678.

13. Wakakura M, Minei-Higa R, Oono S, et al. Baseline features of idiopathic optic neuritis as determined by a multicenter treatment trial in Japan. Jpn J Ophthalmol 1999;43:127-132.

14. Bradley WG, Whittey WM. Acute optic neuritis: its clinical features and their relation to prognosis for recovery of vision. $\mathrm{J}$ Neurol Neurosurg Psychiatry 1967;30:531-538.

15. Rizzo JF, Lessell S. Optic neuritis and ischemic optic neuropathy. Overlapping clinical profiles. Arch Ophthalmol 1991;109:1668-1672.

16. Kupersmith MJ, Nelson JI, Seiple WH, Carr RE, Weiss PA. The 20/20 eye in multiple sclerosis. Neurology 1983;33:1015-1020.

17. Ashworth B, Aspinall PA, MitchellJD. Visual function in multiple sclerosis. Doc Ophthalmol 1990;73:209-224.

18. Martinelli V, Comi G, Filippi M, et al. Paraclinical tests in acute-onset optic neuritis, basal data and results of a short follow up. Acta Neurol Scand 1991;84:231-236.

19. Morrissey SP, Miller DH, Kendall BE, et al. The significance of brain magnetic resonance imaging abnormalities at presentation with clinically isolated syndromes suggestive of multiple sclerosis. A 5-year follow-up study. Brain 1993;116:135-146.

20. Beck RW, Arrington J, Murtagh FR, et al. Brain MRI in acute optic neuritis: experience of the Optic Neuritis Study Group. Arch Neurol 1993;8:841-846.

21. Frederiksen JL, Larsson GBW, Henriksen O, Elesen J. Magnetic resonance imaging of the brain in patients with acute monosymptomatic optic neuritis. Acta Neurol Scand 1989;80:512-517.

22. Jacobs L, Munschauer FE, Kaba SE. Clinical and magnetic resonance imaging in optic neuritis. Neurology 1991;41:15-19.

23. Beck RW, Cleary PA, Anderson MA, et al. A randomized, controlled trial of corticosteroid in the treatment of acute optic neuritis. N Engl J Med 1992;326:581-588.

24. Glaser GH, Merritt HH. Effects of corticotrophin (ACTH) and cortisone on disorders of the nervous system. JAMA 1952;148:898-904.

25. Quinn JR, Wolfson WQ. Improved results from individualized intensive hormonal treatment in certain eye diseases reported to respond poorly to ACTH or cortisone. Univ Mich Med Bull 1952;18:1-26.

26. Kazdan P, Kennedy RJ. Intravenous treatment of optic neuritis. Arch Ophthalmol 1955;53:700-701.

27. Rucker CW. Optic neuritis of unknown etiology. Trans Am Acad Ophthalmol Otolaryngol 1956;60:93-96.

28. Giles CL, Isaacson JD. The treatment of acute optic neuritis. Arch Ophthalmol 1961;66:52-55.

29. Oksala A. Cortisone therapy in fasciculitis optica. Ophthalmologica 1964;148:13-24.

30. Rawson MD, Liversedge LA, Goldfarb G, McGill BA. Treatment of acute retrobulbar neuritis with corticotrophin. Lancet 1966;2:1044-1046.

31. Rawson MD, Liversedge LA. Treatment of retrobulbar neuritis with corticotrophin. Lancet 1969;2:222. 
32. Bowden AN, Bowden PMA, Friedman AI, et al. A trial of corticotrophin gelatin injection in acute optic neuritis. J Neurol Neurosurg Psychiatry 1974;37:869-873.

33. Gould ES, Bird AC, Leaver PK, McDonald WI. Treatment of optic neuritis by retrobulbar injection of triamcinolone. Br Med J 1977;1:1485-1497.

34. Mehdorn E. Megadose steroid therapy in papillitis with progressive visual loss (in German). Klin Monatsbl Augenheilkd 1990;197:506-513.

35. van Engelen BG, Hommes OR, Pinckers A, et al. Improved vision after intravenous immunoglobulin in stable demyelinating optic neuritis. Ann Neurol 1992;32:834-835.

36. Sanders EA, Volkers AC, van der Poel JC, van Lith GH. Estimation of visual function after optic neuritis; a comparison of clinical tests. Br J Ophthalmol 1986;70-72.

37. Fleishman JA, Beck RW, Linares OA, Klein JW. Deficits in visual function after resolution of optic neuritis. Ophthalmology 1987;94:1029-1035.

38. Budning AS, Gans M, Filer R, Greenberg S. Visual function after optic neuritis: a preliminary study. Can J Ophthalmol 199;26:18-20.

39. Trauzettel-Klosinski S, Aulhorn E, Diener HD, et al. Effect of prednisolone on the course of optic neuritis. Results of a doubleblind study. Fortschr Ophthalmol 1991;88:490-501.

40. Herishanu YO, Badarna S, Sarov B, et al. A possible harmful late effect of methylprednisolone therapy on a time cluster of optic neuritis. Acta Neurol Scand 1989;80:569-574.

41. Spoor TC, Rockwell DL. Treatment of optic neuritis with intravenous megadose corticosteroid. A consecutive series. Ophthalmology 1988;95:131-134.

42. Farris BK, Pickard DJ. Bilateral postinfectious optic neuritis and intravenous steroid therapy in children. Ophthalmology 1990;97:339-345.

43. Rollinson RD. Bilateral optic neuritis in childhood. Med J Aust 1977;2:50-51.

44. Gerling J, Kommerell G. Short term effect of megadose steroid therapy in optic neuritis. Klin Monatsbl Augenheilkd 1992;201:375-380.

45. Perry HD, Mallen FJ, Grodin RW, Cossari AJ. Reversible blindness in optic neuritis associated with influenza vaccination. Ann Ophthalmol 1979;11:545-550.

46. Hepler RS. Management of optic neuritis. Surv Ophthalmol 1976;20:350-357.

47. Dinning WJ. Steroids and the eye - indications and complications. Postgrad Med J 1976;52:634-638.

48. Nano HM, Perez HA, Beraza H, Grayeb E. Optic neuritis. Treatment with hydrocortisone injections. Arch Oftalmol B Aries 1970;45:322-328.

49. Huang SY, Zeng YC. Clinical observations on treatment of disorders of the optic nerve by acupuncture. J Trad Chin Med 1985;5:187-190.

50. Ershkovich IG, Gol'dfel'd NG, Koza RI. The value of glycerin and retrobulbar injections of hydrocortisone in the treatment of neuritis of the optic nerve. Oftalmol Zh 1969;24:322-328.

51. Schmidt D. Treatment of optic neuritis. Bull Soc Belge Ophtalmol 1983;208:93-96.

52. Hallermann W, Haller P, Kruger C, Schiemann M, Patzold U. Progress of optic neuritis with and without corticosteroid treatment. Findings in a long term investigation with static perimetry. Fortschr Ophthalmol 1983;80:30-34.

53. Toczolowski J, Lewandowska-Furmanik M, Stelmasiak Z, Wozniak D, Chmiel M. Treatment of acute optic neuritis with large doses of corticosteroids. Klin Oczna 1995;97:122-125.

54. Koraszewska-Matuszewska B, Samochowiec-Donocik E, Rynkiewicz E. Optic neuritis in children and adolescents. Klin Oczna 1995;97:207-210.

55. Alejandro PM, Castanon-Gonzalez JA, Miranda-Ruiz R, et al. Comparative treatment of acute optic neuritis with boluses of intravenous methylprednisolone or oral prednisone. Gaceta Medica de Mexico 1994;130:227-230.

56. Kapoor R, Miller DH, Jones SJ, et al. Effects of intravenous methylprednisolone on outcome in MRI-based prognostic subgroups in acute optic neuritis. Neurology 1998;50:230-237.

57. Trauzettel-Klosinski S, Axmann D, Diener HC. The Tübingen Study on optic neuritis treatment: a prospective, randomized and controlled trial. Clin Vis Sci 1993;8:385-394.

58. Wakakura M, Mashimo K, Oono Shinji et al. Multicenter clinical trial for evaluating methylprednisolone pulse treatment of idiopathic optic neuritis in Japan. Jpn J Ophthalmol 1999;43:133-138.

59. Sellebjerg F, Nielsen HS, Frederiksen JL, Olesen J. A randomized, controlled trial of oral high-dose methylprednisolone in acute optic neuritis. Neurology 1999;52:1479-1484.

60. Soderstrom M, Jin Y-P, Hillert J, Link H. Optic neuritis. Prognosis for multiple sclerosis from MRI, CSF, and HLA findings. Neurology 1998;50:708-714.

61. Beck RW. The Optic Neuritis Treatment Trial: implications for clinical practice. Arch Ophthalmol 1992;110:331-332.

62. Beck RW. Corticosteroid treatment of optic neuritis: a need to change treatment practices. Neurology 1992;42:1133-1135.

63. Beck RW, Kupersmith MJ, Cleary PA, et al. Fellow eye abnormalities in acute unilateral optic neuritis: experience of the Optic Neuritis Treatment Trial. Ophthalmology 1993;100:691-698.

64. Keltner JL, Johnson CA, Spurr JO, et al. Baseline visual field profile of optic neuritis. The experience of the Optic Neuritis Treatment Trial. Arch Ophthalmol 1993;111:231-234.

65. Cleary PA, Beck RW, Anderson MM, et al. Design, methods and conduct of the Optic Neuritis Treatment Trial. Control Clin Trials 1993;14:123-142.

66. Keltner JL, Johnson CA, Beck RW, et al. Quality control functions of the Visual Field Reading Center (VFRC) For The Optic Neuritis Treatment Trial (ONTT). Control Clin Trials 1993;14:143-159.

67. Beck RW, Cleary PA, Optic Neuritis Study Group. Recovery from severe visual loss in optic neuritis. Arch Ophthalmol 1993;111:300. 
68. Beck RW, Diehl L, Cleary PA, et al. The Pelli-Robson Letter Chart: normative data for young adults. Clin Vis Sci 1993;8:207210.

69. Chrousos GA, Kattah JC, Beck RW, et al. Side effects of glucocorticoid treatment: experience of the Optic Neuritis Treatment Trial. JAMA 1993;269:2110-2112.

70. Beck RW, Cleary PA, et al. Optic Neuritis Treatment Trial: one-year follow-up results. Arch Ophthalmol 1993;111:773-775.

71. Beck RW, Cleary PA, Trobe JD, et al. The effect of corticosteroid for acute optic neuritis on the subsequent development of multiple sclerosis. N Engl J Med 1993;329:1764-1769.

72. Keltner JL, Johnson CA, Spurr JO, et al. Visual field profile of optic neuritis: one-year follow-up in the Optic Neuritis Treatment Trial. Arch Ophthalmol 1994;112:946-953.

73. Beck RW, Cleary PA, Backlund JC, et al. The course of visual recovery after optic neuritis. Experience of the Optic Neuritis Treatment Trial. Ophthalmology 1994;101:1771-1778.

74. Kupersmith MJ, Kaufman D, Paty DW, et al. Megadose corticosteroid in multiple sclerosis. Neurology 1994;44:1-4.

75. Beck RW. The Optic Neuritis Treatment Trial: three-year follow-up results. Arch Ophthalmol 1995;113:136-137.

76. Beck RW, Trobe JD. The Optic Neuritis Treatment Trial: putting the results in perspective. J Neuroophthalmol 1995;15:131-135.

77. Rolak LA, Beck RW, Paty DW, et al. Cerebrospinal fluid in acute optic neuritis: experience of the Optic Neuritis Treatment Trial. Neurology 1996;46:368-372.

78. Goodin DS. Corticosteroids and optic neuritis. Neurology 1993;43:632-633.Letter.

79. Goodkin DE, Rudick RA, Kinkel R, Ransohoff RM. Corticosteroids and optic neuritis. Neurology 1993;43:632-633.Letter.

80. Beck RW, Optic Neuritis Study Group. Corticosteroids and optic neuritis. Neurology 1993;43:633-634.Letter.

81. Goodin DS. Treatment of optic neuritis. Neurology 1993;43:2731.Letter.

82. Beck RW, Optic Neuritis Study Group. Treatment of optic neuritis. Neurology 1993;43:2731.Letter.

83. Optic Neuritis Study Group. The 5-year risk of MS after optic neuritis. Neurology 1997:49:1404-1413.

84. Optic Neuritis Treatment Trial Manual of Operations. Springfield, VA: National Technical Information Service, 1990 (NTIS accession no. PB90-195728).

85. Optic Neuritis Treatment Group. Visual function 5 years after optic neuritis: experience of the Optic Neuritis Treatment Trial. Arch Ophthalmol 1997;115:1545-1552.

86. Beck RW, Trobe JD, for the Optic Neuritis Study Group. What we have learned from the Optic Neuritis Treatment Trial. Ophthalmology 1995;102:1504-1508.

87. Silberberg DH. Corticosteroids and optic neuritis. N Engl J Med 1993;329:1808-1810.

88. Goodin DS. Perils and pitfalls in the interpretation of clinical trials: a reflection on the recent experience in multiple sclerosis. Neuroepidemiology 1999;18:53-63.

89. Rose AS, Kuzma JW, Kurtzke JF, et al. Cooperative study in the evaluation of therapy in multiple sclerosis. ACTH vs placebofinal report. Neurology 1970;20:1-59.

90. Cox TA, Woolson RF. Steroid treatment of optic neuritis. Arch Ophthalmol 1981;99:338.

91. Cole SR, Beck RW, Moke PS, Kaufman DI, Tourtellotte WW, Optic Neuritis Study Group. The predicative value of CSF oligoclonal banding for MS 5 years after optic neuritis. Neurology 1998;51:885-887.

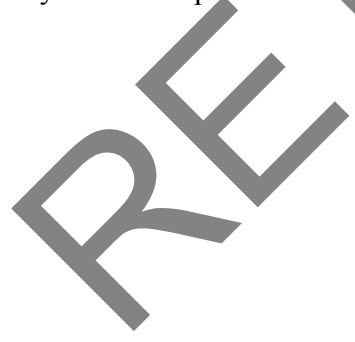




\section{Neurology}

Practice parameter: The role of corticosteroids in the management of acute monosymptomatic optic neuritis [RETIRED]: Report of the Quality Standards

Subcommittee of the American Academy of Neurology

D.I. Kaufman, J.D. Trobe, E.R. Eggenberger, et al.

Neurology 2000;54;2039-2044

DOI 10.1212/WNL.54.11.2039

This information is current as of June 13, 2000

Updated Information \&

Services

Citations

Permissions \& Licensing

Reprints including high resolution figures, can be found at:

http://n.neurology.org/content/54/11/2039.full

This article has been cited by 4 HighWire-hosted articles:

http://n.neurology.org/content/54/11/2039.full\#\#otherarticles

Information about reproducing this article in parts (figures,tables) or in its entirety can be found online at:

http://www.neurology.org/about/about_the_journal\#permissions

Information about ordering reprints can be found online:

http://n.neurology.org/subscribers/advertise

Neurology ${ }^{\circledR}$ is the official journal of the American Academy of Neurology. Published continuously since 1951, it is now a weekly with 48 issues per year. Copyright . All rights reserved. Print ISSN: 0028-3878. Online ISSN: 1526-632X.

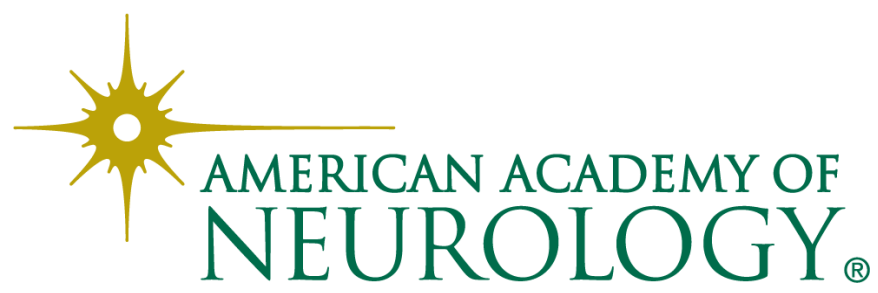

